\title{
COOPERATIVE ARCHITECTURE Creative and Social Design Modes as Urban Practice
}

R. Cappeller M.Sc. M.A.

IES, Faculty of Architecture and Landscape Sciences, Leibniz Universität Hannover, Germany

\begin{abstract}
Directing towards future modes for architectural design in existing urban contexts, the concept of cooperative architecture is defined, looking not only at future urban spaces lived, used and designed in cooperation, but also the representation, understanding and communication of space as well as ways of working at the intersection with other disciplines. To start the discussion three reference projects were examined, showing the complexity of their social and spatial relations as a curated exhibition thought as format for exchange and discussion. Highlighting the spatial qualities, atmosphere and cultural capacity of the cooperative architectures understood as lived spaces, qualitative research methods and an inventive exploration helped to bring together the collected material and try a first categorization. Curation in this sense is used as a research tool to experiment and reflect, positioning the act of researching in a changing and interdisciplinary context that opts towards a future process of architecture and urban design as creative and social attitude.
\end{abstract}

Keywords (4): Lived Space, cooperative architecture, creative and social design methods, cultural heritage

Thematic clusters: urban design and public space 


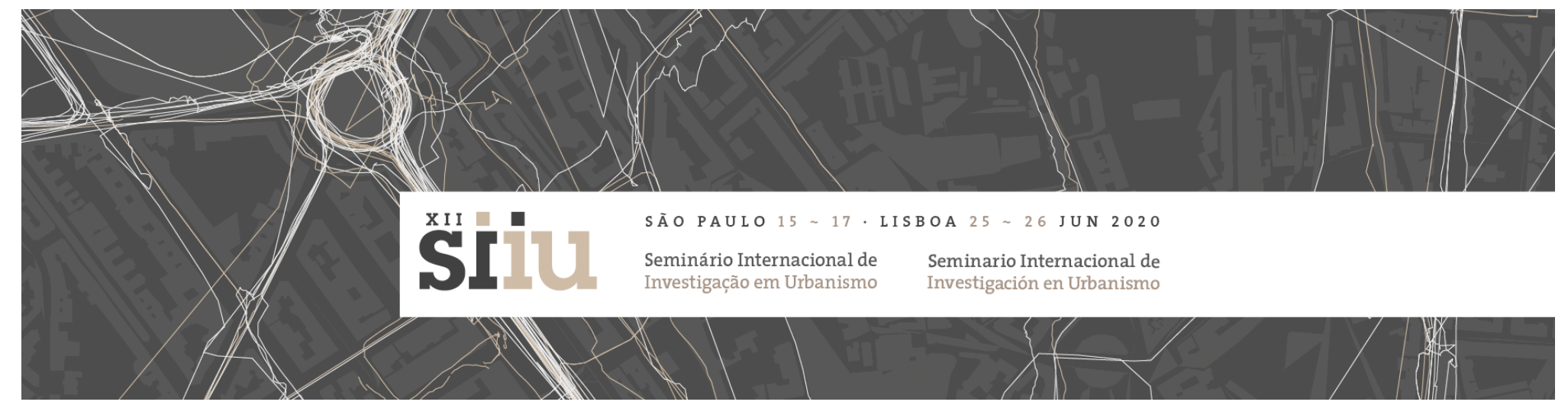

moving away from a market-oriented interest or an investor controlled development; the creation and transformation of the space in shared authorship as well as the cultural capacity contained, enabling sociability and exchange. Following these principals, the selection of the three cases is not connected to a specific spatial setting or strategic position, but to their social emergence and an existing spatial possibility, allowing the unexpected to happen. They are not understood as goal-oriented projects, but as processes of socially and spatially oriented decisions, formulating a base for an open, tolerant society and important part of politics and culture.

The analysis of the three case studies is important, as they are exemplary urban developments, showing topics of interconnection in a social, cultural, economic, ecologic and of course also spatial sense, emerging in actual urban design discussions and possible solutions and a necessarily changing role and attitude of the "spatial practicioners" - architects, urban designers or other spatial actors - here strongly involved on site. The space's value lies in the cultural and creative aspects contained, their presence in society and the merging of bottom-up and top-down processes as well as showing a strong engagement of the users in place and society that together with the architects and urban designers, which in the cases are often part of the users group, challenge the legal framework and interpret regulations creatively.

They were examined through a first approach and own inventive exploration, a creative analysis connected to the "As Found" - a new seeing of the ordinary, an openness as to how prosaic "things" could re-energise our inventive activity." (Alison Smithson 1959) The field research and on site exploration were carried out through qualitative interviews with the architects, designers or initiators of the processes and the collection of archive materials or review of existing literature. Space was not only recorded documentary but experienced sensually, applying visual and inventive methods - photographing, filming, sketching and "writing the sites" (Rendall 2006) The act of writing draws on spaces as they are remembered, imagined and observed following the idea of space of collective memory and action, formulating narratives to bring together various perspectives, layers and scales. The so collected data was then mapped, categorized and put up for discussion through a multimedia-installation that helped to better understand and communicate the spatial qualities and performative aspects contained. It was the starting point for a reflexive practice directed towards a critical and analytical field between theory and practice, leading to further debates on co-designing, changing and -producing spaces through a process oriented, open-ended design approach. It aims at understanding cooperative architecture as Lived space and relevant concept for future spatial production through the reference projects.

The second research part (Perspectives on Cooperative Architectures) helps to broaden the gained understanding of a more complex concept of space with ideas, perspectives and associations produced as artistic interpretations and reflective work with different methods, expressing the through vision and motion perceived spatial situations (Maholy-Nagy 1947) and their way of conceptualization and realisation. Brought together as combination of visual representations and a critical reflection on the applied urban practice which bring together top down and bottom up processes, in which the people in space actively engage. In qualitative and explorative interviews with some of the involved producers the different spatial expressions and cultural science based understandings of space will be questioned. Examples here raise from the spatial soundworks of Janett Cardiff and George Miller, over writings following Georges Perecs observation modes to theatre plays like "Großbaustelle" by Rimini Protokoll, where visitors step by step arrive at an understanding of the complex processes inherent in six situations, the inside perspectives of them and their in-between connections which as a meta concept is experienced when zooming out. 


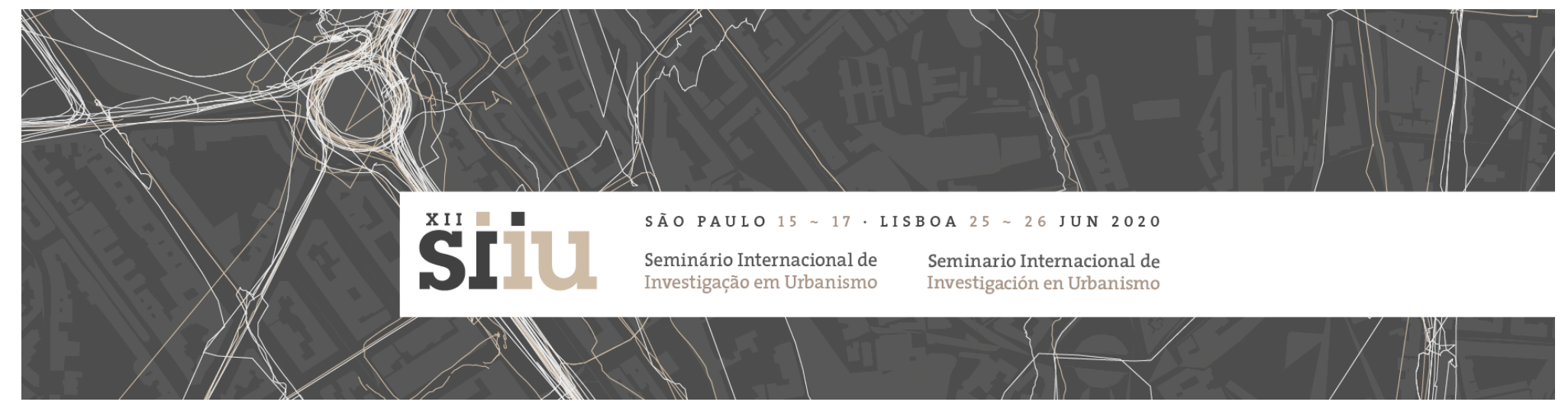

During the third part of research (Modes and laboratories of design research) these ideas will be connected and used in a different way as collaboratively produced design research formats applied in urban practice. They approach, think, design and produce space collectively and work at the intersection of a material and spatial design and its everyday-use that references the idea of Happenings (Gordon Matta Clark). Criticism and reflexivity in this laboratory - situation is challenged as a form of knowledge production. "Site writing" as described for the first part of the research here takes one step more as a performative language production. It is at the same time reflection and expression, realized in a collaborative working process that creates new scenarios, concepts and imaginations. Within the design research projects already undergone in teaching to develop possible tools for architectural design, the history and memory connected to a space always played an important role and was used as a "can opener" (Corboz 1978) to the further reflection and the collection of material that then could be interpret. Working with sound, film and writing when conceptualizing and designing space has led to experimental and collaborative working formats which in the repertoire of architectural and urban design modes have to be discussed much more in detail.

\section{Context: The city as framework and ressource}

The today's city in which ideas of cooperative architecture are located, can be interpret as "augmented city" (Carta 2017) characterized as a growing, fragmented, multicultural and complex city, that is open, inclusive and creative, putting an emphasis on already existing gaps and spaces that have to be developed. Also the "creative city" (Landry and Bianchini 1995), that highlights the always needed creativity for cities to work as markets, have a mix of races and culture, create new ideas through interaction and allow people to live their ideas, is an interesting concept within this context. In both cases the complexity of the city is seen as a ressource that requires a multidimensional understanding of space and a more flexible and improvising action (Finkenberger, Baumeister, Koch 2019)

The three reference projects examined in the following work as new platforms for social exchange, allowing an ongoing and flexible process of spatial change and adaption, transmitting social values through a collective memory attached to them and creating nodes of creative experience that help to derive tools as options for a resource bound action. Lived spaces are socially influenced and subjectively perceived spaces that gain their significance through practice and use in the everyday, implementing changing processes and thinking physical and social space together (Lefebvre 1974, Boudon 1969). They allow us to think of the city "not only as level of reality, but collective mode of reflection" (Boeri 2004), which deal with the existing and are dynamic constellations, cultural artefacts and "performative characters of the processes of designing" (Wolfrum. p.84) that "give rise to a continuous reinvention of the meanings or re-imagination of a site" (Miles, in Cartiere and Willis 2008) Also Jane Jacobs states "old materials are needed to reinvent the cultural life of inner-city environments and seen to resist high speed capitalisation (1963)." The selected reference projects therefore show built urban situations as "fluid entities in the making" (Latour/Yaneva/Geiser 2008) - the different projects as ongoing processes.

City - making is seen as social process, a relationship between social and physical shaping of cities, between how people use, create and live in social spaces, and the formal and informal material as well as embodied production of urban environments (Tonkiss 2013) The city has a cumulative capacity, that is transformed by accumulation, addition and superimposition, demanding reuse and the reconversion of existing urban 

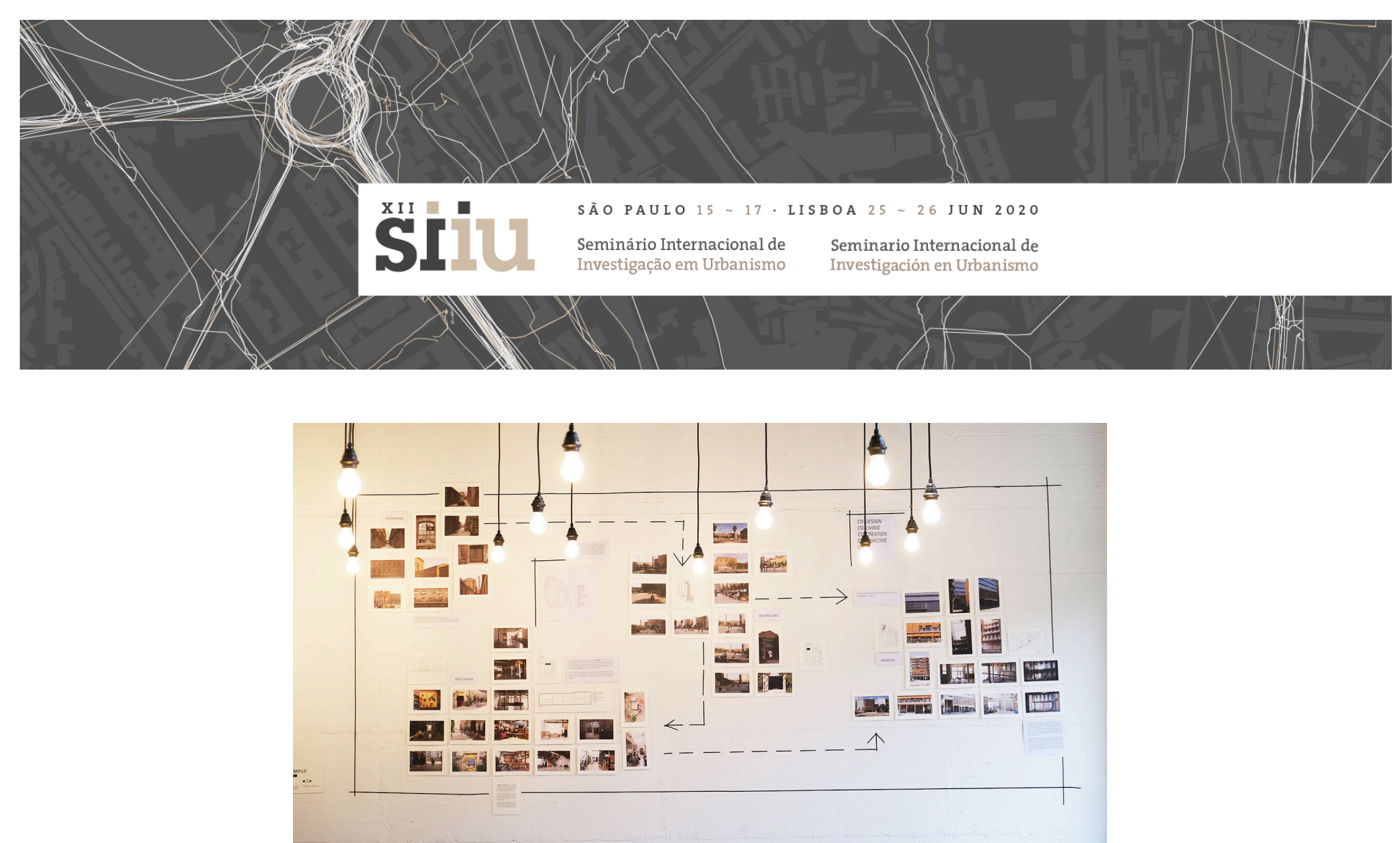

Fig. 07 Collage of collaboratively managed spatial situations at Can Batllo (Own creation)

Can Batllo stands for the cooperative models of organisation, financing and design and the combination of old and new as montage of social action and spatial manifestation. It is a spatial tool for the reshaping and experimentation of society and offers possibilities for social and spatial production, experimentation and flexible use. As a montage in film it is a series of short shots sequenced to condense space, time, and information. It shows the complexity and coexistance of various actors in different sites of intervention that through accupuncture provoke small changes, creating a freespace open to everyone - "a space for opportunity, a democratic space, un-programmed and free for uses not yet conceived. There is an exchange between people and buildings that happens, even if not intended or designed." (Farrrell \& Mcnamara 2018)

The three projects were used to give an idea of what kind of space is imagined in this research as a mixed urban future space and to understand the complexity and layers connected to it. Space through its interdependency with social actions in this sense works as integrating and cultural connection point that has to be designed, lived and expressed differently than through the approven architectural repertoire. We have to (re)read the patina of existing spaces and the continuous material inscription that tells of its uses (Kaijima 2018) to change their function or add on situations "as found" (Smithsons). Making buildings speak and allow them to tell their process through the interaction of social, cultural and economic ideas that form them, could be one approach -actively living, discussing and performing a place, an other.

\section{Reflections on researching and curating}

"Practice based research allows us to think differently and recognize the discipline on its own terms - look beyond the text" (Lucas 2016, p. 44) It points out the necessity of a possible shift within the role and working fields of architects and urban designers activating, designing and communicating space. Therefore to change the researchers perspective leads to a more reflexive understanding of the subject itself and positions it within a broader research. Reflexivity is an important constant learning tool (Watt 2007). From a passively observing, theoretically routed researcher, to one collecting data of any kind and bringing it together into a new format as a bricoleur, or being between the expertise of an architect, a reporter, a sociologist, an actively taking part user of a space and the curator, the role of the researcher here is shifting all the time. Also a curator today 


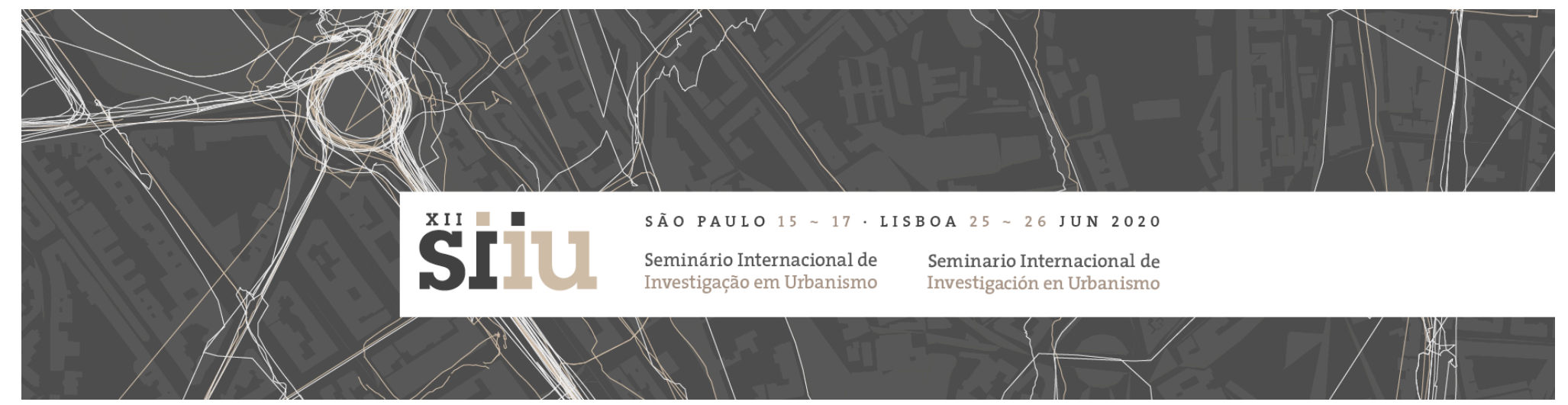

has an expanded role as active producer, reinventing a setting over and over again (Puwar and Sharma 2012) which overlaps with the idea of architecture, being a material practice and making discipline that has to constantly approach, think and (re-)invent the complexity of urban spaces.

Following Nilsson "new relationships between theory and practice, between research and practical designing, between academia, architectural practice and different actors in society, must be articulated and established through conscious strategies." (2013) I would therefore argue that the question of the public brings in another role - the one of a communicator and research facilitator that is important in order to make visible the contribution of architecture and urban design to the development of our society. Knowledge creation in architecture and design is always connected to the making - even within the discipline of design research it stays important to address this active mode of production and "do" (design) while thinking, reflecting, and writing. An activist researcher according Scaffidi, Lopez Franco and Sharkey, facilitates social change and empowerment and can affect long-term change of a place by contributing in theory and practice, defining new models and procedures (2019) which is also a goal of this research.

\section{Conclusion}

To sum up the presented ideas and the first approach towards an open concept of cooperative architecture, bringing together Lived Spaces and ideas to continue the research with interdisciplinary perspectives and active modes of collaborative design shows the importance to reconsider aspects already existing in the spaces surrounding us and already giving ideas about how space can be thought and done differently, evoking people's engagement in their own living environment. Curating findings and observations more, could help to create a further understanding of the layers of well functioning urban spaces and work on the communication of their main features. Also I would argue that the understanding of design not only as aesthetic intervention, but much more as a socially and culturally routed practice expressed through the idea of the social sculpture (Exrotaprint), Collective conversations and intensive examination through performative urbanism (Granby Four Streets) and the idea of a freespace and the accupuncture of space (Can Batllo) expressing and questioning directions of our society brings it back to the public discussion and opens new possibilities. The conventional ways of transporting architectural ideas is not enough anymore and has to shift from the focus on buildings and their two-dimensional presentation to its users and the transformation over time - the living process. Representing situations of cooperative architecture (spaces, perspectives and possible ways of working) that already bear a certain level of complexity shows this connection, the social and spatial qualities and the importance of acting together as well as the impossibility of a single person - as the hedonistic image of the architect still existent makes believe - to react to cooperation in political models, changing live situations, the mix of people and uses in their everyday life, mobilities and ways of working. We need different ways of working that also include a more general question on the formation of our material and lived spaces, try to create networks and leads to a much more culturally and society rooted understanding and formation of space.

\section{REFERENCES}

ALLEN, D. S. (2020) Politische Gleichheit. Berlin: Suhrkamp. 


\section{SÃOPAULO15 17 LISBOA $25 \sim 26$ JUN 2020}

AMIN, A. \& NIGEL, T. (2002) Cities: Reimagining the Urban. Oxford: Blackwell Publishing Ltd, p. 1-30.

BIANCHINI, F. \& LANDRY, C. (1995) The creative city. London: Demos.

BOERI, S. (2001) Multiplicities, in: Koolhaas, R: Mutations. Barcelona: Actar

KOOLHAAS, R. (2001) Mutations. Barcelona: Actar

BUCHERT, M. (Ed.) (2014) Reflexives Entwerfen. Berlin:Jovis

CARTA, M. (2017) The Augmented City

CARTIERE, C. \& WILLIS, S. (Eds.) (2008) The Practice of Public Art, London: Routledge

CORBOZ, A. (1978) Old Buildings and Modern Functions. Lotus International 13 (December): 69-79

ECKARDT, F. (2004) Soziologie der Stadt. Themen der Soziologie. Bielefeld: transcript Verlag

FARRELL,Y. \& MCNAMARA, S. (2018) Manifesto Freespace

FINKENBERGER, I. M. \& BAUMEISTER, E.-M. \& KOCH, C. (Eds) (2019) Komplement und Verstärker. Zum Verhältnis von Stadtplanung, künstlerischen Praktiken und Kulturinstitutionen. Jovis:Berlin

GLASER, BARNEY G.\& STRAUSS \& ANSELM L.(1998) Grounded Theory: Strategien qualitativer Forschung. Hubert Verlag, Bern

JACOBS, J. (1963) Death and Life o great american cities

KAIJIMA,M.; STALDER,L.; ISEKI, Y. (2018) Architectural Ethnography - Japanese Pavilion Venice Biennale 2018. Toto Verlag

LUCAS, R. (2016) Research methods for architecture. London: Laurenne King Publishing

MOHOLY-NAGY, L. (1947) Vision in motion, Chicago: Paul Theobald and Company.

MÜLLER, W. \& GUALLART, V. \& SORIANO, F, et al. (Eds) (2003). The Metapolis dictionary of advanced architecture: city, technology and society in the information age. Barcelona: Actar.

NILSSON, F. (2013) „Knowledge in the Making. On Production and Communication of Knowledge in the Material Practices of Architecture“. FormAkademisk - forskningstidsskrift for design og designdidaktikk 6 (2). https://doi.org/10.7577/formakademisk.569.

PENZ, F. (2017) Cinematic Aided Design: An Everyday Life Approach to Architecture , Abingdon: Taylor \& Francis Ltd. 
PEREC, G. (1974) Species of spaces and other pieces. London: Penguin Classics

PUWAR, N. \& SHARMA, S. (2012) 'Curating Sociology'. The Sociological Review Vol. 60 (1), pp. 40-63.

RENDELL, J. (2006) Site writing. The Architecture of Art Criticism. London: IB Tauris

SHARKEY, M. \& LOPEZ FRANCO, M. \& MOTTEE L.K. \& SCAFFIDI, F. (2019). Activist Researchers: Four Cases of Affecting Change. plaNext - next generation planning. 8: 10-20. DOI: 10.24306/plnxt/42.

TILL, J. (2007) What is architectural research? Architectural Research: Three Myths And One Model. London: Riba

TONKISS, F. (2013) Cities by Design, Polity Press: Cambridge

WATT, D. (2007). On becoming a qualitative researcher: The value of reflexivity. The Qualitative Report, 12(1), 82-101. Retrieved [25.02.2020], from http://www.nova.edu/ssss/QR/QR12-1/watt.pdf

WOLFRUM, S. (2015) Peformative Urbanism. Jovis:Berlin

YANEVA, A. \& LATOUR, B. \& GEISER, R. (ed.) (2008) Explorations in Architecture: Teaching, Design, Research. Basel: Birkhäuser, p. 80-89

ZARDINI, M. (2012) Toward a sensorial urbanism. Ambiances in action / Ambiances en acte(s) - International Congress on Ambiances, Montreal, pp.19-26 